\title{
Effective management of socio-economic development of municipalities: experience in developing and implementing a professional retraining program for city managers
}

\author{
Vitaly Makoveev ${ }^{1}$, and Andrey Barabanov ${ }^{2}$, Irina Akhmetova ${ }^{3}$ \\ ${ }^{1}$ Vologda state University \\ ${ }^{2}$ Vologda branch of the Russian presidential Academy of national economy and public administration \\ ${ }^{3}$ Kazan State Power Engineering University, str. Krasnoselskaya, 51, 420066, Kazan, Russia
}

\begin{abstract}
Sustainable long-term development of the energy industry in remote areas is impossible without qualified personnel in the field of management. In this regard, modern approaches to managing the socioeconomic development of municipalities are studied. It is shown that it is necessary to organize and conduct professional training and retraining of local government management personnel (city managers), which is primarily aimed at obtaining new knowledge, skills and competencies in the field of territorial development management. The experience of developing and implementing a professional retraining program for city managers based on the Vologda branch of RANEPA is summarized and presented.
\end{abstract}

\section{Introduction}

Local self-government in the Russian Federation is one of the foundations of the constitutional system. This is the closest level of government to the population. Wellorganized local self-government makes it possible to meet the basic living needs of the population, effectively using the available local resources, and, thus, to relieve social tension and increase public confidence in the authorities on the territory of the municipality [9].

The economic and social reforms carried out in the country expand the functions of local self-government bodies, the content of their work and powers, which makes the problem of managing the socio-economic development of municipalities particularly relevant.

The modern management paradigm is based on a systematic approach to the object of management and consideration of all elements of the system in dynamics and interaction between themselves and the external environment. The implementation of this paradigm at the municipal level is based on such modern approaches to managing the socio-economic development of territories as strategic planning, program-target and project management. The latter approach is particularly relevant due to a lack of resources, increased competition, and a significant increase in the volume of information.

Project management is a special type of management activity based on the preliminary collective development of a model of actions to achieve the original goal and aimed at implementing this model. In its turn, the project is a system set of planned (financial, technological, and other) documents containing a model of actions aimed at achieving the original goal [2].
Implementation of the project approach in modern conditions at the municipal level creates a need for specialists who possess new knowledge and management skills, are able to act effectively and competently, and widely use new technologies of municipal management and public service.

A modern city Manager should be [7]:

- leader who can extend his influence to the entire team and to each individual;

- qualified professional not only in the practice of management technologies, but also in the industry specifics;

- innovator who understands the role of innovative changes in management and knows how to use them in their activities;

- mentor and educator with high moral standards, flexibility and ability to persuade, tolerance for mistakes made but corrected by subordinates, and other pedagogical competencies;

- diplomat who knows how to resolve problematic situations in a team;

- creative organizer of the production and management process.

This makes it necessary to organize and conduct professional training and retraining of local government management personnel (city managers), which is primarily aimed at obtaining new knowledge, skills and competencies in the field of territorial development management.

The relevance of training management personnel in the Vologda region is determined by the active transition of the region to a new model, which assumes the presence of the Institute of the head of local administration, appointed on a competitive basis. 
The Vologda branch of RANEPA became a training platform for the educational stage of the regional project "Governor's Team: municipal level" [6]. Participants of the educational stage are 35 representatives from 20 municipalities of the region who passed the competitive selection. Training of managerial personnel was carried out under a state contract with the Department of public service and personnel policy of the Vologda region.

Specialists of the Vologda branch of RANEPA developed a professional retraining program "Effective municipal management (city Manager)" (504 hours).

Factors influencing the formation of targets and the content of the program were:

- compliance with the customer's requirements for the execution of the contract;

- taking into account the specifics of the socioeconomic policy of the region;

- taking into account the requirements for professional knowledge, skills and abilities required to perform the duties of a city Manager, the level of professional training and managerial experience of students;

- accounting of the Federal state and municipal ADMINISTRATION, regulations in the field of education, modern educational technologies and experience in implementing similar programs.

The main goal of professional retraining programs is the formation or improvement of competencies in new types of professional activities. The types of activities of students of the program "Effective management of municipal education (city manager)" are determined based on the analysis of materials of legal regulation and the formation of the Institute of city managers in Russia. City manager is a contract manager, a specialist in municipal management. During the competitive selection process, the candidate for the position must prepare and defend a project for the socio-economic development of the municipality at a meeting of the representative body.

All this has determined the program's targets - the priority choice of training students for organizational, managerial and project activities. The formation of design skills in municipal management today is the most relevant for effective business managers.

In addition, the analysis of the problems of the target audience allowed us to pay attention to their needs for the organization of the educational stage. Potential city managers include current municipal employees, managers with technical and economic education, aged from 30 to 49 years. A small group consisted of specialists who were not previously associated with the management of the municipality, but have experience in managing the organization. Thus, the students needed to improve their professional skills in management and develop new knowledge about approaches to innovative municipal management, taking into account the current problems of socio-economic development of the region and the municipality.

The educational process consisted of 5 modules (modules of legal disciplines, socio-psychological, economic, managerial, module "management of municipal economy"), which are distributed over three training sessions. The topics of the sessions are determined based on the content of the module disciplines and step-by-step improvement and acquisition of new knowledge: 1st session is "Organizational and economic foundations of local selfgovernment and management of individual economic complexes"; 2nd session is "development of human resources. Basics of interaction and partnerships"; 3rd Session is "management efficiency and development of the municipality".

Through the use of a network form that provides the opportunity to develop the program with the involvement of the resources of the main campus, leading teachers of the RANEPA participated in the educational process.

Building horizontal links and forming a business network of representatives of local governments and regional Executive authorities is one of the main tasks of the project. Therefore, within the framework of the training, students interact with competent expertspractitioners from the Executive authorities of the region. Heads and specialists of the Department of public service and personnel policy of the region, the Department of internal policy of the regional government, the state legal Department of the regional government, the state order Committee of the region updated the priority directions of regional policy to city managers during round tables and business games.

The program included traditional and innovative educational technologies. A distinctive feature of the program "Effective management of municipal education (city Manager)" is the use of educational technologies such as:

- field sessions to study the most effective experience of socio-economic development of municipalities in the region and other regions;

- learning the inter-sessional period;

- project-based learning approach.

Field sessions included the following forms of training: presentation of the experience of socioeconomic development of the municipality; round tables and meetings with heads of state authorities in charge of the district and (or) the field of study, seminars and consultations; brainstorming sessions on support, development and prospects for practical application of ideas for the development of municipalities; study of objects of the social sphere of the municipality; on-thejob internships.

The participants studied the sites of effective experience of socio-economic development of the Vologda region (Nikolsky district) and Yaroslavl region (Myshkinsky and Danilovsky districts). During the sessions, the theory and practice of applying project management solutions in the development of territories were studied, and initiatives for their practical application were discussed. The visiting sessions were moderated by the heads of regional authorities (O. A. Vasiliev, Deputy Governor of the Vologda region, and V. V. Prijateljev, head of the Department of state service and personnel policy of the Vologda region).

During the inter-sessional training period, students participated in scientific and practical conferences and forums on the development of municipalities in order to 
study the experience of mechanisms for implementing best practices in local issues in the country and regions. Thus, 12 municipal employees were part of the regional delegation to the all-Russian forum "Involving citizens in local self-government: current municipal practice". All participants participated in the panel discussions of the regional scientific and practical conference "management of territories and economic entities in conditions of economic instability: global challenges and development mechanisms".

Project work is focused on the training of management teams, the formation of relevant for modern managers ability to develop socio-economic projects, the ability to manage the project, to get high-quality results. Project teams were formed based on the main directions of development of the municipality and consisted of no more than 4 people.

The project method included the following stages of training:

1. Formation of a project group, team building training (module of socio-psychological disciplines).

2. Translation of theoretical knowledge about design methods (module "municipal management", module of management disciplines).

3. Definition and protection of the topic relevant for the development of the territory of the municipality (module "municipal management").

4. Teamwork, round tables and meetings with experts of regional Executive authorities, development and execution of projects (module "municipal management", module of legal disciplines, module of economic disciplines).

5. Independent work during the inter-sessional period, working distant contacts; internship to study the experience of other regions in implementing socioeconomic projects of municipalities; adjustment, preparation for protection and pre-protection of projects;

6. Public defense of the project with the participation of experts from the regional Executive authorities.

Development and implementation of the project includes 4 main stages:

1. project Initiation (definition of the goal, project expertise, appointment of the project management team, approval of the project passport).

2. Project planning (search, analysis, selection, elaboration and refinement of the paths).

3. Project implementation (execution of works, monitoring and adjustment).

4. Closing the project (completion of execution or execution of refusal to fulfill obligations, disbanding the organizational structure of the project).

Participants of the program presented projects covering the most relevant areas of development of the municipality, taking into account regional characteristics. Special attention of the project groups was focused on the development and implementation of areas of economic diversification, development of municipal-private partnership in housing and communal services, increasing investment activity in the territory, organizing inter-municipal cooperation, using the tourism potential as a tool for ensuring sustainable development, developing a model for involving small businesses and the population in the development of priority sectors of the economy, improving energy efficiency management of territories.

The tutor-moderator and expert practitioners ensured the project's managerial relevance during the development process.

General stages of tutor support:

a) diagnostic (identification of the group's cognitive interest in the project);

b) formulation of the primary question and on its basis the topic of the proposed research (creative work, project, etc.); $\mathrm{C}$

) drawing up a search map (where, in what spaces, sources, you can find the answer to the question);

d) choosing the basic tools for working with sources (How will I get information? To handle it? Present it?);

e) the actual " research»;

f) processing and analyzing the results; choosing the method of processing the results and presenting them (to the customer, expert practitioner);

g) analyzing and presenting the results of project activities.

Thus, the tutor-moderator of the final project work plans and ensures all stages of its implementation, organizes the systematic activities of the project team and advises it on the organization and content of work on the project.

Protection of the project that is relevant for the development of municipalities in the region was the main element and criterion for successful completion of the professional training program by participants.

Thus, the organization and conduct of professional retraining of city managers on a regular basis will improve their knowledge and skills, acquire new competencies in the field of management, which in turn will allow a more in-depth and detailed approach to the development and implementation of projects in various areas of socio-economic development of territories.

\section{References}

1. A. O. Vylegzhanina, Multiproject management and project management systems, 160 (Direct-Media, 2015)

2. P. V. Ivanov, N. I. Turyanskaya, E. G. Subbotina, project Management, 251 (Phoenix, 2016)

3. Federal law No. 131-FZ of 06.10.2003 (as amended on 30.10.2017)"on General principles of organization of local self-government in the Russian Federation".

4. The Federal law of 02.03.2007 № 25-FZ (edited on 26.07.2017) "On municipal service in the Russian Federation".

5. Law of the Vologda region of December 10, 2014 No. 3529-OZ "on certain issues of organization and activity of local self-government bodies in the territory of the Vologda region".

6. Official website of the Governor of the Vologda region [Electronic resource]. Mode of access: http://okuvshinnikov.ru/proekty/ 
komanda_gubernatora_municipalnyj__uroven/o brawenie_gubernatora_2.

7. I. Nikulina, Praktiko-competency approach in the preparation of the personnel reserve, Problems of management theory and practice, 6, 108-116 (2014)

8. I. Toioradze, A. dmitrik, project Management as a stage of process management, Problems of management theory and practice, 2, 93-100 (2013)

9. E. S. Shugrina, Report on the state of local selfgovernment in the Russian Federation: current challenges and development prospects, 312, (Moscow: Prospect publishing House, 2013)

10. Center for project management [Electronic
[ resource]. Mode of access: https://pm.center.

11. V.V. Kolmakov, A. G. Polyakova, S. V. Karpova, and A. N. Golovina, Cluster Development Based on Competitive Specialization of Regions, Economy of Region 15 (1), 270-284 (2019). doi:10.17059/2019$1-21$. 